\title{
Research on Challenges Faced with College English Teachers and Promotion Paths under the Background of Belt and Road
}

\author{
Rong Du \\ School of Foreign Studies, Xi'an University, 710065, China
}

Keywords: College English teachers, Belt and Road, Promotion paths

\begin{abstract}
The professional development of college English teachers is closely related to the teaching level and the quality of education. Since the implementation of the strategy of Belt and Road in China, the opening-up degree has been improved a lot. College English teachers are faced with the challenges of the absent of business knowledge, short of practical experience and lack of learning ability. This paper analyzes the challenges and gives corresponding suggestions to help College English teachers to promote themselves under the background of Belt and Road.
\end{abstract}

\section{Introduction}

"Belt and Road” is proposed to build" Silk Road Economic Belt and "21st Century Maritime Silk Road”. The core content is summarized as" five aspects of policy communication facilities, Unicom, trade flow, capital circulation, the people connected. With the implementation of the development strategy of Chinese Belt and Road Initiative, economic globalization, the large employment market for foreign language talents, but also provide new opportunities for "Silk Road Economic Belt" and "maritime Silk Road Economic Belt" consists of countries and regions for the future development of foreign language talents, including the implementation of the strategy of trade. Transportation, finance, business, tourism, science and technology, culture and other fields, multilateral economic cooperation. This requires a group of high-level, applied and professional foreign language talents who have a strong ability to apply foreign language, and have a relatively systematic knowledge of international business, with international vision and cross-cultural communication ability. Therefore, it is a common problem for our foreign language education to enlarge the depth and breadth of business English talents training. The quality of business foreign language teachers not only affects the quality of business foreign language talents training, but also affects the realization of business foreign language training objectives. Therefore, the study of the construction of compound business foreign language teaching team has practical significance. English is the most widely used language in the world today. Different language and different cultural communication mainly depend on English. It is foreseeable that in the future for a long time, the language of the countries along the line is mainly English. In countries along the road, there is no country like Britain, the United States and other countries, the English as a mother tongue. In other words, these countries are all non-English speaking countries, and English is a lingua franca for communication in these countries. This is a new problem and challenge for college English teachers.

\section{Challenges Faced with College English Teachers under the Background of Belt and Road}

\subsection{Absence of Business Knowledge}

Although most English teachers have a solid foreign language skills and cross-cultural communication ability, but lack of business related industry background knowledge, in the teaching process involved in the subject knowledge mainly rely on teachers' self-study. Due to the limited understanding of business knowledge, the teaching of business knowledge in class is relatively superficial or inaccurate, which affects students' mastery of knowledge. In this case, some colleges 
and universities with the help of economics related professional teachers, such as international trade, to complete the teaching of business professional knowledge, to take the language, culture and business added mode. But economics teachers often focus on explaining business knowledge, language and cultural knowledge is poor, and mostly taught mainly in Chinese language and professional knowledge cannot be well integrated, leading students three knowledge modules disjointed, difficult to achieve comprehensive knowledge and practice. A few business foreign language teachers from enterprises know business operation mode, and also have rich industry practice experience, but lack of systematic foreign language knowledge structure and the theory and experience of education and teaching, liquidity is strong, also difficult to manage. The latter two kinds of business English teachers have their own shortcomings, which directly affect the business ability and quality of business foreign language graduates. Under the background of the new era, College English teachers should master the knowledge of qualified solid education, psychology, linguistics and other related professional, College English teachers only through timely supplement and update their knowledge to grasp the background and characteristics of the students, to do a good job of teaching. But since the college enrollment expansion, English teachers' workload is relatively heavy, and the students' English is relatively weak, many teachers are busy teaching work and do not have sufficient time and energy to enrich their professional knowledge, self-development is slow, and therefore affected the teaching quality.

\subsection{Short of Practical Experience}

Traditional foreign language teachers usually carry out teaching activities through the grammatical analysis of words and sentences, and there are also the same problems in business foreign language teaching. Business foreign language is a highly practical and practical subject. Students of business English major should improve their professional skills through continuous practice to meet the social needs. If the theoretical teaching is dominant, it will lead to three distinctive features of "language class", "business class" and "cross cultural communication class" in the course of business foreign language teaching, and the teaching objectives are not clear, which will affect the quality of personnel training. In addition, the business of foreign language teachers in the teaching and the scientific research burden, lack of professional training and learning opportunities, young teachers lack of experience and other factors, but also restricts the development of teachers' personal occupation, it will not only affect the realization of business English teachers become the target compound teachers, also hindered the sustainable development of business English discipline. Teachers should have rich industry background knowledge and certain professional practical experience, and introduce and teach students' business knowledge, such as product search, marketing strategy, social etiquette, negotiation skills and so on, to guide students' practical activities in English. From an English teacher to an excellent business English teacher, teachers must expand their business knowledge and enrich their own practical experience, and promote the combination of theory and practice. According to the interview results, it is necessary for business English teachers to study and practice in enterprises or other institutions, and have a more comprehensive understanding of international business knowledge, rather than relying solely on books to master business knowledge. In order to improve the overall quality of English teachers, the school can invite rich entrepreneurs or experts to give lectures or seminars in the school, and English teachers can also participate in professional training in some institutions.

\subsection{Lack of Learning Ability}

With the rapid development of society and economy, the economy has realized globalization, and education has been internationalized. English plays an important role in the international language. Learning English well plays an important role in the development of an individual in the future. Students tend to have an aversion to English ideas, therefore, as an English teacher must recognize the importance of their work, do their own work. With the continuous development of network technology, under the influence of network technology and multimedia technology, people realize the importance of English. As an English teacher, we also need to constantly update their English level, 
exercise their English teaching ability. In the background of new curriculum reform, English teachers have realized the importance of autonomous learning, how to continuously improve their autonomous learning ability in English we need teachers to recognize the current drawbacks in terms of autonomous learning found problems in a timely manner to solve problems to continuously improve their autonomous learning ability. In the teaching process, each coach will encourage and require students to learn autonomously, but coach often will only care about whether students to independent learning, while ignoring their own as a teacher should also be self-regulated learning and constantly enhance their work ability and teaching level. Influenced by the traditional teaching mode, teachers occupy the dominant position in teaching. If they can solve the learning problems that students may encounter, the importance of lifelong learning is completely ignored. The premise of cultivating lifelong learning is the habit of self-study. In the process of teaching reality, there will always be students to ask questions and he cannot solve the problem of the status quo, it is fully proved the importance of lifelong learning.

\section{Promotion Paths of College English Teachers under the Background of Belt and Road}

\subsection{Study Business Knowledge}

To achieve the goal of not only depends on the subject orientation of advanced education idea, reasonable and perfect curriculum system of business English talents and more complex, depends on a high-quality team of teachers, because the design of business English teachers are not only the business English subject of vision, it is also a practitioner of this vision. Therefore, in a certain sense, the quality of the team can not only become the bottleneck of the development of business English discipline, but also become a driving force for the development of discipline and compound talents. The characteristics of business English require that business English teachers should not only be an effective transmitter of classroom teaching information, but also be a researcher with higher English language proficiency, and a scholar who is familiar with professional knowledge of business. The complex characteristics of business English determine the duality or combination of the language skills and business knowledge of business English teachers. It is the combination of teachers' ability and quality that is the basis and guarantee for realizing the goal of cultivating compound and Applied Business English talents. Therefore, during business English construction, we must do the following 3 things in the development of business English teachers' ability, and the training of Applied Business English talents requires that teachers have the language and business knowledge background needed for talent training. Of course, this does not mean that every teacher needs this kind of compound quality, and the combination of teachers can be embodied in both the individual teachers and the teachers. As far as the teacher's "individual compound" is concerned, some famous universities in China are in the leading position and have a large number of compound teachers. However, most colleges and universities still face challenges and shoulder heavy responsibilities in this respect.

\subsection{Do Social Practice}

Business foreign language discipline is different from other disciplines, and it requires higher teachers' practical experience. Practical experience helps to better integrate theory with practice, make teaching visualize and concrete, so that students can quickly put into practical operation, less detours, as soon as possible to meet the needs of society. To solve this problem, we should pay attention to both inside and outside the school". First, education departments should publish relevant policy system, encourage enterprises and universities to carry out friendly cooperation, accept business enterprise language teachers to practice, and actively cooperate with the school of business English teachers' ability of objective assessment, provide an institutional guarantee for teacher training. Secondly, from the school point of view, we can set up a reward mechanism to encourage teachers to exercise in enterprises, or set up special departments related to teacher training to achieve the docking between teachers and enterprises. For Higher Vocational English teachers trained by pure language education, it is necessary to determine their own development direction as early as 
possible according to the professional needs of their own interests, and expand their own professional knowledge field. Expand the professional knowledge training system in addition to a professional, it is better to read the study of relevant professional information, attend professional courses, and often professional practitioners or practitioners to consult students, can also participate in various training, including the occupation qualification examination in related majors, participate in academic seminars, scientific research, study visits, online learning, cooperative research etc. In the process of determining the industry of English teachers in some schools, teachers in respect of interest at the same time, also consider whether teachers family members or relatives with relevant professional background, so as to provide support for teachers' transformation, this is a kind of humanized management mode, is worth promoting.

\subsection{Enhance Learning Ability}

English teachers' ideas should keep up the pace of Belt and Road Initiative "development strategy, get rid of the shackles of traditional ideas, enhance the consciousness of international business English. We strengthen the sense of responsibility and urgency in teaching business foreign languages. Secondly, multi-level training should be carried out according to the current situation of the teaching staff. According to the situation of the transformation of teachers' business knowledge and lack of skills, can take sent learning, encourage inter professional admitted to doctoral students, professional background knowledge or relying on the school discipline school of foreign languages and the advantage of using law, management, tourism cooperation and other ways to make the existing training college foreign language teachers access system; for the introduction from the enterprise in personnel can be transported to the colleges and universities strengthen language training and teaching ability. Complementary research and teaching, how to cultivate "Belt and Road" background of foreign language talents, how to carry out the curriculum, how to carry out the construction of teaching material, it is worth studying. In the process of scientific research, teachers' knowledge has been deepened and their quality has been improved. Business English teachers are generally young and have great potential for development, but they lack all kinds of experience. Therefore, the scientific research team can be established to help young teachers improve the level of scientific research, and teachers' scientific research projects should be correctly regulated and reasonably guided. Application of dry Internet plus education raises the teaching pattern and teaching method reform. Foreign language teachers are one of the key factors to achieve the integration of foreign language teaching and advanced educational technology in the process of using modern educational technology to conduct classroom and guide students to study independently. In the use of multimedia and network technology in the teaching of teachers, in addition to strengthen the production capacity and the development of multimedia courseware of computer operating skills, but also the need to form a team of teachers, to expand cooperation in Business English courses, build course flipping the classroom, online and offline combination, promote the innovation of business English teaching mode.

\section{Conclusion}

Strategic conception of "The Belt and Road" will give the development of our country brought great challenges and opportunities. At present, our country is "Belt and Road" strategy to promote, College English teachers should learn business knowledge, participate in extracurricular practice and enhance the learning ability to improve the quality of English teaching, English training more high-quality, promote better service to the strategy.

\section{References}

[1] Liu Zhongyang. New Thoughts for English Specialty Construction in West Chinese Universities under the New Situation of “One Belt and One Road” [J]. Future and Development,.2015(6): 72-75.

[2] Wang Hongyi, Yang Liu. College English Teachers Professional Development: Challenges and 
Countermeasures [J]. Journal of Yichun College, 2013, 35(11): 136-139.

[3] Yang Shanshan. The Community Construction of College English Teachers' Professional Development in Western Ethnic Areas in the Background of Belt and Road Initiative [J]. Jouranl of Hezhou University, 2017, 33(1): 109-112.

[4] Zhang Guangyong. New Problems English Education and Their Solutions in the Context of "The Belt and Road” [J]. Language Education, 2017, 5(1): 2-6+13. 